\title{
ANALISIS PENGARUH METODE PERBAIKAN TANAH VACUUM PRELOADING TERHADAP STRUKTUR ABUTMENT DI SEKITARNYA
}

\author{
Steven Djunawan ${ }^{1}$ dan Andryan Suhendra² \\ ${ }^{1}$ Program Studi Sarjana Teknik Sipil, Universitas Tarumanagara, Jl. Letjen S. Parman No.1 Jakarta \\ steven.325170078@stu.untar.ac.id \\ ${ }^{2}$ Program Studi Sarjana Teknik Sipil, Universitas Tarumanagara, Jl. Letjen S. Parman No.1 Jakarta \\ andryansuhendra@yahoo.com
}

Masuk: 12-07-2021, revisi: 07-08-2021, diterima untuk diterbitkan: 19-08-2021

\begin{abstract}
Soft soil in Indonesia is problematic in infrastructure development because of its low bearing capacity and takes a long time to consolidate. In general, the method used to overcome soft soil is vacuum preloading combined with prefabricated vertical drain, PVD. The purpose of the initial loading is to consolidate the soft soil layer with a load equal to or greater than the soil load during and after construction. Meanwhile, vertical drainage can support the consolidation process. However, this method can also cause lateral movement which also affects the area outside the repair. Thus, it is necessary to model the influence distance analysis from the circumference of the repair area outside the repair. Analysis and modeling using $2 D$ finite program elements that will be compared with results in field. The results of the comparison of the settlement for 260 days shows a different chart pattern but a corresponding final settlement. The modeling shows that the largest influence distance due to the lateral movement is cell 2, which is $11,23 \mathrm{~m}$. While the distance from the abutment to the repair area is $15 \mathrm{~m}$. Therefore, the lateral movement of the vacuum preloading soil improvement project does not affect the surrounding abutments.
\end{abstract}

Keywords: prefabricated vertical drain (PVD), vacuum preloading, lateral movement, $2 D$ finite program elements

\begin{abstract}
ABSTRAK
Tanah lunak di Indonesia menjadi problematika pada pembangunan infrastruktur dikarenakan daya dukung yang rendah serta memakan waktu penurunan konsolidasi yang lama. Pada umumnya, perbaikan tanah yang digunakan untuk mengatasi tanah lunak adalah vacuum preloading yang dikombinasikan dengan prefabricated vertical drain, PVD. Tujuan pembebanan awal adalah untuk mengkonsolidasikan lapisan tanah lunak dengan beban sama atau lebih besar dari beban tanah selama dan setelah konstruksi. Sementara drainase vertikal dapat mempercepat proses konsolidasi. Namun, metode ini juga dapat penyebabkan pergerakan lateral yang juga mempengaruhi area diluar perbaikan. Sehingga, dibutuhkan pemodelan analisis jarak pengaruh dari keliling daerah perbaikan ke daerah luar perbaikan. Analisis dan pemodelan menggunakan program elemen hingga 2D yang akan dibandingkan dengan hasil lapangan. Hasil perbandingan penurunan selama 260 hari menunjukan pola grafik yang berbeda namun penurunan akhir yang sesuai. Pemodelan menunjukan jarak pengaruh terbesar akibat pergerakan lateral berada pada cell 2 yaitu $11,23 \mathrm{~m}$. Sementara jarak abutment ke daerah perbaikan 15m. Maka pergerkan lateral pada proyek perbaikan tanah vacuum preloading tidak mempengaruhi abutment di sekitarnya.
\end{abstract}

Kata kunci: prefabricated vertical drain (PVD), vacuum preloading, pergerakan lateral, program elemen hingga 2D

\section{PENDAHULUAN}

Dalam beberapa dekade terakhir, terjadi peningkatan infrastruktur baik pada sektor industri, transportasi, pemukiman, serta perdagangan. Di sisi lain, tanah lunak di Indonesia cukup tersebar secara merata. Maka tidak jarang infrastruktur yang dibangun di Indonesia mempunyai jenis tanah lunak.

Tanah lunak menjadi problematika pada pembangunan infrastruktur. Tanah lunak yang jenuh dengan air mempunyai sifat kompresibilitas yang tinggi serta permeabilitas yang pada umumnya rendah. Selain penurunan konsolidasi yang dialami akan memakan waktu yang cukup lama, daya dukung tanah juga cukup rendah sehingga menyebabkan penurunan yang berlebih. Hal tersebut mengakibatkan pentingnya metode perbaikan tanah (soil improvement) pada proyek pembangunan di tanah lunak. 
Perbaikan tanah yang umum digunakan pada masalah ini adalah dengan metode vacuum preloading yang dikombinasikan dengan drainase vertikal pracetak (Prefabricated Vertical Drain, PVD). Pada prinsipnya, metode ini menerapkan tekanan negatif ke lapisan tanah oleh pompa vacuum. Lalu, PVD dipasang ke dalam tanah sehingga lintasan air pada tanah tereduksi. Selain mempercepat konsolidasi yang dapat mempersingkat waktu konstruksi, kombinasi dua metode ini juga sering kali mengehemat biaya sehingga pekerjaan lebih ekonomis.

Kombinasi metode vacuum preloading dan PVD tidak hanya menyebabkan penurunan pada tanah dasar, tetapi juga menyebabkan terjadinya perpindahan lateral ke luar sehingga merusak daerah sekeliling daerah perbaikan. Penelitian ini akan difokuskan pada jarak pengaruh antara batas area yang diperbaiki dan area terluar yang diperbaiki untuk mencegah kerusakan bangunan atau utilitas di sekitar area yang diperbaiki dengan menyesuaikan kedalaman PVD. Diperkirakan kedalaman PVD dapat mengurangi jarak dampak.

\section{Penurunan Konsolidasi Primer}

Penurunan konsolidasi adalah penurunan yang terjadi akibat terdisipasinya tegangan air pori dalam tanah dengan undrained menuju tanah dengan kondisi drained. Konsolidasi sebagai proses keluarnya air atau udara dari dalam pori tanah, deformasi partikel tanah, serta relokasi partikel yang disebabkan oleh beban tambahan pada tanah. (Das B. M., 1994). Penurunan konsolidasi primer adalah penurunan yang disebabkan oleh perubahan volume tanah selama proses pengeluaran air pori dari tanah. Selama penurunan ini, karena penarikan air pori, tekanan air pori terus berubah menjadi tegangan efektif. Penurunan konsolidasi semacam ini biasanya terjadi pada lapisan tanah kohesif (clay / lempung). Pada lempung jenuh, peningkatan tegangan total akan ditransfer ke air pori dan partikel tanah.

Menurut Das B. M. (1994), Jika tegangan efektif overburden lebih kecil dari tegangan yang pernah dialami oleh tanah tersebut sebelumnya, maka tanah akan terkonsolidasi lebih (over consolidated) terjadi. Sementara jika tegangan efektif overburden lebih kecil dari tegangan yang pernah dialami oleh tanah tersebut sebelumnya, maka tanah akan terkonsolidasi normal (normally consolidated) terjadi.

Tanah normally consolidated dapat dihitung dengan rumus berikut:

$$
S_{c}=\frac{C_{c} H}{1+e_{0}} \log \left(\frac{\sigma_{0^{\prime}}+\Delta \sigma}{\sigma_{0^{\prime}}}\right)
$$

Tanah over consolidated dapat dihitung dengan rumus berikut:

i. Bila $\sigma_{0}^{\prime}+\Delta \sigma \leq \sigma_{c}$, maka:

$$
S_{c}=\frac{C_{S} H}{1+e_{0}} \log \left(\frac{\sigma_{0^{\prime}}+\Delta \sigma}{\sigma_{0^{\prime}}}\right)
$$

ii. Bila $\sigma_{0}^{\prime}+\Delta \sigma>\sigma_{c}$, maka:

$$
S_{c}=\frac{C_{S} \cdot H}{1+e_{0}} \log \left(\frac{\sigma_{c^{\prime}}}{\sigma_{0^{\prime}}}\right)+\frac{C_{S} \cdot H}{1+e_{0}} \log \left(\frac{\sigma_{0}^{\prime}+\Delta \sigma}{\sigma_{c}}\right)
$$

\section{Vacuum preloading}

Vacuum preloading merupakan metode perbaikan tanah yang sering digunakan oleh banyak perusahaan geoteknik untuk pekerjaan perbaikan tanah. Tekanan vacuum yang diterapkan bisa sampai $90 \mathrm{kPa}$, walaupun dalam praktek tekanan vakum yang sering digunakan hanya sekitar $80 \mathrm{kPa}$ (Chu, 2008). Namun, jika beban yang dibutuhkan untuk mencapai target perbaikan tanah lebih besar dari $80 \mathrm{kPa}$, beban lain dapat ditambahkan di atas sistem vakum. Dari segi beban yang dibutuhkan dan luas yang sama, cara ini bisa dikatakan lebih murah dibandingkan dengan metode fill surcharge. Sistem vacuum preloading bias dilihat pada gambar 1:

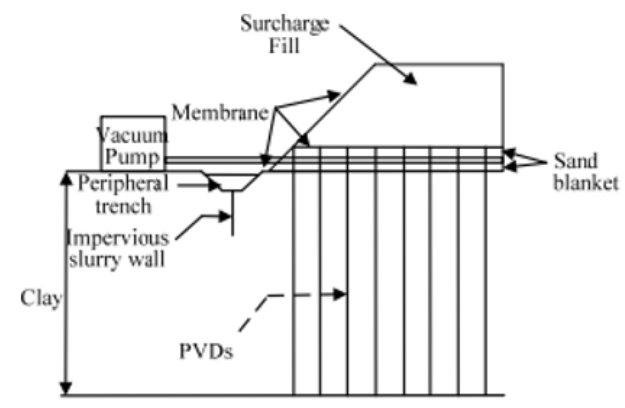

Gambar 1. Sistem vacuum preloading (Sumber: Indraratna B. R., 2005)

Peralatan ini terdiri dari sistem drainase vertikal dengan lapisan drainase diatasnya (lapisan pasir). Lapisan pasir tersebut ditutupi oleh lapisan yang kedap air. Drainase horizontal dipasang pada lapisan drainase dan berhubungan 
langsung dengan pompa vacuum. Untuk menjaga kelembapan udara, membrane kedap air itu ditempatkan pada dasar dari saluran yang diisi penuh dengan bentonite. (Lay, Sumarli, \& Iskandar, 2020) Tegangan negatif tersebut akan menghasilkan negative pore water pressure, yang disebabkan oleh meningkatnya nilai tegangan efektif pada tanah sehingga dapat menyebabkan terjadinya konsolidasi pada tanah. (Indraratna, 2005)

\section{Prefabricated Vertical Drain (PVD)}

Pemampatan yang dilakukan membutuhkan waktu yang sangat lama, maka dibutuhkan percepatan dalam pemampatan tanah. Salah satu metode perbaikan tanah untuk mempercepat waktu konsolidasi adalah dengan menggunakan Vertical Drain. Vertical drain dapat diklasifikasikan menjadi 3 (tiga) tipe umum, yaitu : sand drain, fabric encased drain, dan prefabricated vertical drain (PVD). Adapun untuk PVD itu sendiri bisa berupa karton, textile, plastik, atau material lainnya (bahan karung dan sabut kelapa). Pada umumnya PVD banyak digunakan karena kemudahan pemasangan di lapangan. Tiang-tiang atau lubang-lubang tersebut "dipasang" di dalam tanah pada jarak tertentu sehingga memperpendek jarak aliran drainase air pori (drainage path) (Mochtar, 2000).

Menurut Badan Standarisasi Nasional (2017), PVD dapat digunakan pada pembangunan pekerjaan di darat dan di laut untuk tujuan sebagai mengurangi besaran penurunan setelah pembangunan, mempercepat proses konsolidasi dengan mengurangi panjang lintasan disipasi tegangan air pori berlebih, meningkatkan stabilitas (dengan menaikkan tegangan efektif dalam tanah) dan mengurangi efek likuifaksi.

\section{Instrumen geoteknik}

Instrumen geoteknik adalah perangkat geoteknik yang mempelajari perilaku tanah. Pemasangan instrumen geoteknik pada perbaikan tanah berfungsi untuk memantau proses pelaksanaan selama pekerjaan berlangsung dan mengetahui kinerja hasil pekerjaan perbaikan tanah yang telah dilakukan. Instrume-instrumen yang ada seperti inclinometer, settlement plate, piezometer.

\section{Koefisien Permeabilitas Tanah (k)}

Koefisien permeabilitas tanah (k) juga sering disebut sebagai kecepatan air yang mengalir pada lapisan tanah, sehingga satuan koefisien ini adalah satuan jarak per satuan waktu. Semakin kecil partikel tanah, semakin kecil rongga antar partikel, sehingga semakin lambat aliran air di lapisan tanah. Oleh karena itu, pada tanah seperti lempung, kecepatan aliran air relatif lambat. Tabel 1 menunjukan koefisien permeabilitas berdasarkan jenis tanah.

Tabel 1. Koefisien Permeabilitas (Das B. M., 1994)

\begin{tabular}{cc}
\hline Jenis Tanah & $\begin{array}{c}\text { Koefisien Permeabilitas, k } \\
(\mathbf{m} / \mathbf{d e t i k})\end{array}$ \\
\hline Butiran Kasar & $10^{-2}-1$ \\
Kerikil Halus & $10^{-5}-10^{-2}$ \\
Pasir Halus, Lanau Longgar & $10^{-7}-10^{-5}$ \\
Lanau Padat, Lanau Berlempung & $10^{-8}-10^{-7}$ \\
Lempung Berlanau, Lempung & $10^{-11}-10^{-8}$ \\
\hline
\end{tabular}

\section{METODE PENELITIAN}

\section{Metodologi dan pengolaan data}

Metodologi penelitian yang dilakukan dalam penulisan ini diawali dengan data perencanaan dimana data awal yang dimiliki untuk perencanaan, studi literatur dimana mengumpulkan teori-teori yang digunakan untuk melakukan analisis penurunan tanah dan metode perbaikan tanah berupa buku-buku, jurnal, dan tutorial. Kemudian menganalisis data perencanaan yang mengkorelasikan data-data tanah yang ada dan menentukan parameterparameter yang dibutuhkan perhitungan. Hasil perhitungan dari penulisan ini menggunakan program elemen hingga. Dimana analisis hasil dengan melakukan perbandingan pembacaan dengan lapangan dengan yang di program, serta pemodelan pengaruh lateral pada struktur sekitar.

\section{Diagram alir}

Langkah-langkah yang akan dilakukan pada penelitian digambarkan pada alir penelitian seperti pada gambar 2. 


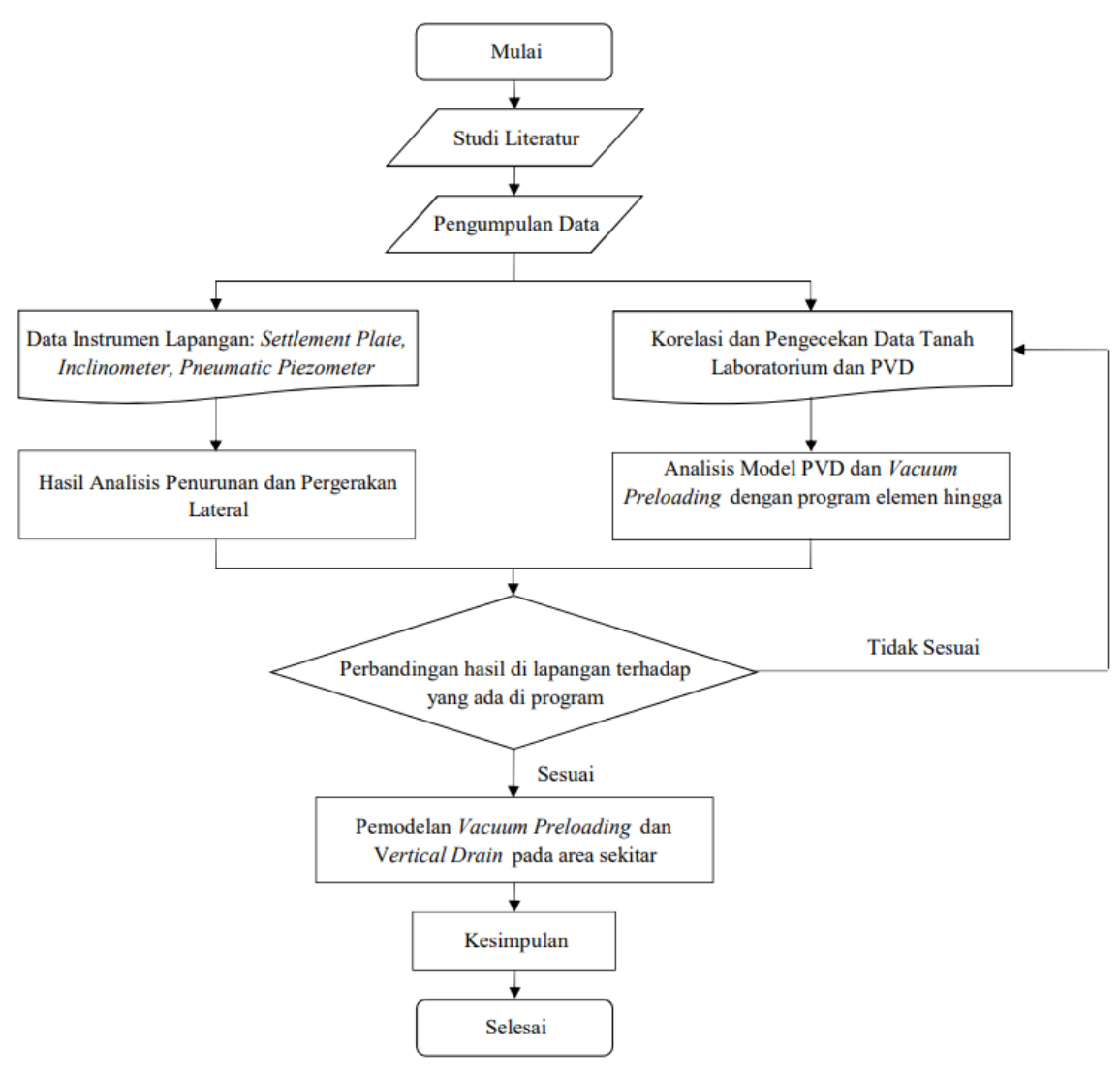

Gambar 2. Diagram Bagan Alir

\section{HASIL DAN PEMBAHASAN}

Dari hasil pengumpulan data, data diolah untuk mendapatkan hasil akhir penurunan, tekanan pori, pergerakan lateral, serta parameter-parameter tanah yang sesuai dengan keadaan di lapangan.

Vertical drain dipasang pada area dengan rincian pemasangan sebagai berikut:

- Kedalaman pemasangan

$$
\begin{array}{lll}
\text { - Kedalaman pemasangan } & : 12,5 \mathrm{~m} \text { (cell 1) dan 15m (cell 2,3 dan 4) } \\
\text { - Pola pemasangan } & : \text { Persegi } \\
\text { - Lebar vertical drains (a) } & : 100 \mathrm{~mm} \\
\text { - Tebal vertical drains (b) } & : 4 \mathrm{~mm}
\end{array}
$$$$
\text { - Lebar vertical drains (a) : } 100 \mathrm{~mm}
$$$$
\text { - Jarak antar PVD (s) : } 1 \mathrm{~m}
$$

Jarak Abutment dengan daerah luar perbaikan adalah sepanjang $15 \mathrm{~m}$.

\section{Penentuan Parameter Tanah}

Setelah jenis tanah pada masing-masing lubang bor telah diketahui, maka dilakukan evaluasi berdasarkan data tanah yang ada. Nilai parameter yang ada pada tabel tersebut menggunakan korelasi data sondir dan data boring.

Sampel tanah diambil hingga kedalaman rata-rata 15 meter. Dari hasil sampel tanah tersebut terlihat bahwa muka air tanah terbaca di kedalaman 1,2m untuk cell 1 dan 3,85m untuk cell 2, 3 dan 4 . Tanah dibagi menjadi 4 cell dan pada setiap cell dibagi menjadi 3 bagian. Contoh pada tanah cell 1, dimana tebal lapisan dibagi menjadi menjadi bagian kiri, tengah dan kanan. Secara keseluruhan terdapat tipe tanah organic clays and mixed soils, clayey sands and silt, medium to stiff clay, clayey sands and silt, sandy and silty clays dan sand. Hasil parameter tanah yang digunakan untuk dimasukan untuk program elemen hingga dapat dilihat pada tabel 2 hingga tabel 9. 
Tabel 2. Parameter Tanah Cell 1 Bagian 1

\begin{tabular}{|c|c|c|c|c|c|c|c|}
\hline Daerah & & & & Cell 1 & & & \\
\hline Nomor Lapisan & 1 & 2 & 3 & 4 & 5 & 6 & 7 \\
\hline Jenis Tanah & $\begin{array}{l}\text { Organic } \\
\text { Clays And } \\
\text { Mixed } \\
\text { Soils }\end{array}$ & $\begin{array}{l}\text { Organic } \\
\text { Clays And } \\
\text { Mixed } \\
\text { Soils }\end{array}$ & $\begin{array}{c}\text { Organic } \\
\text { Clays And } \\
\text { Mixed } \\
\text { Soils }\end{array}$ & $\begin{array}{l}\text { Organic } \\
\text { Clays And } \\
\text { Mixed } \\
\text { Soils }\end{array}$ & $\begin{array}{c}\text { Clayey } \\
\text { Sands And } \\
\text { Silt }\end{array}$ & $\begin{array}{l}\text { Organic } \\
\text { Clays And } \\
\text { Mixed } \\
\text { Soils }\end{array}$ & $\begin{array}{l}\text { Medium } \\
\text { Clay }\end{array}$ \\
\hline Tipe & Undrained & Undrained & Undrained & Undrained & Undrained & Undrained & Undrained \\
\hline Tebal Lapisan Pada Sisi Kiri (m) & 0,6 & 0,4 & 3,8 & 2,2 & 0,8 & 4,4 & 0,8 \\
\hline Tebal Kumulatif Pada Sisi Kiri (m) & 0,6 & 1 & 4,8 & 7 & 7,8 & 12,2 & 13 \\
\hline Tebal Lapisan Pada Sisi Tengah (m) & 0 & 1,6 & 0 & 1,8 & 0 & 0 & 0 \\
\hline Tebal Kumulatif Pada Sisi Tengah (m) & 0 & 1,6 & 1,6 & 3,4 & 3,4 & 3,4 & 3,4 \\
\hline Tebal Lapisan Pada Sisi Kanan (m) & 1,6 & 0,8 & 4,2 & 2,4 & 0 & 4 & 0 \\
\hline Tebal Kumulatif Pada Sisi Kanan (m) & 1,6 & 2,4 & 6,6 & 9 & 9 & 13 & 13 \\
\hline rentang qc $\left(\mathrm{kg} / \mathrm{cm}^{\wedge} 2\right)$ & $0-4$ & $5-9$ & $9-15$ & $15-19$ & $18-22$ & $7-12$ & $12-20$ \\
\hline$\gamma$ sat $\left(\mathrm{kN} / \mathrm{m}^{\wedge} 3\right)$ & 14 & 14 & 15 & 15 & 17 & 15 & 17 \\
\hline runsat $(\mathrm{kN} / \mathrm{m} \wedge 3)$ & 13 & 13 & 14 & 14 & 15 & 14 & 15 \\
\hline c $(\mathrm{kN} / \mathrm{m} 2)$ & 2 & 4 & 6 & 10 & 15 & 5 & 14 \\
\hline$\Phi\left(^{0}\right)$ & 10 & 12 & 15 & 16 & 18 & 14 & 16 \\
\hline $\mathrm{E}(\mathrm{kN} / \mathrm{m} 2)$ & 4500 & 5000 & 6000 & 7000 & 10000 & 5500 & 13000 \\
\hline $\mathrm{v}^{\prime}$ & 0,4 & 0,4 & 0,38 & 0,38 & 0,36 & 0,38 & 0,38 \\
\hline Cc & 0,5200 & 0,3500 & 0,2438 & 0,2065 & 0,1975 & 0,3118 & 0,2107 \\
\hline Cs & 0,0720 & 0,0350 & 0,0204 & 0,0106 & 0,0098 & 0,0212 & 0,0111 \\
\hline $\mathrm{e} 0$ & 1,6833 & 0,9981 & 0,7273 & 0,5471 & 0,5306 & 0,7422 & 0,5550 \\
\hline Kx, Ky (m/day) & 0,0000086 & 0,0000086 & 0,0000086 & 0,0000086 & 0,0000086 & 0,0000086 & 0,0000086 \\
\hline $\mathrm{Ck}$ & 0,8417 & 0,4991 & 0,3637 & 0,2736 & 0,2653 & 0,3711 & 0,2775 \\
\hline \multicolumn{8}{|c|}{ Tabel 3. Parameter Tanah Cell 1 Bagian 2} \\
\hline Daerah & & & & Cell 1 & & & \\
\hline Nomor Lapisan & 8 & 9 & 10 & 11 & 12 & 13 & 14 \\
\hline Jenis Tanah & $\begin{array}{c}\text { Clayey } \\
\text { Sands And } \\
\text { Silt }\end{array}$ & $\begin{array}{l}\text { Sandy And } \\
\text { Silty Clays }\end{array}$ & $\begin{array}{c}\text { Clayey } \\
\text { Sands And } \\
\text { Silt }\end{array}$ & Stiff Clay & $\begin{array}{c}\text { Organic } \\
\text { Clays And } \\
\text { Mixed Soils }\end{array}$ & Sand & Sand \\
\hline Tipe & Undrained & Undrained & Undrained & Undrained & Undrained & Drained & Drained \\
\hline Tebal Lapisan Pada Sisi Kiri (m) & 0,6 & 0 & 0 & 0 & 0 & 1,4 & $>0,2$ \\
\hline Tebal Kumulatif Pada Sisi Kiri (m) & 13,6 & 13,6 & 13,6 & 13,6 & 13,6 & 15 & $>15,2$ \\
\hline Tebal Lapisan Pada Sisi Tengah (m) & 6,6 & 1 & 0,8 & 0,4 & 2 & 1 & $>0,2$ \\
\hline Tebal Kumulatif Pada Sisi Tengah (m) & 10 & 11 & 11,8 & 12,2 & 14,2 & 15,2 & $>15,4$ \\
\hline Tebal Lapisan Pada Sisi Kanan (m) & 0,8 & 0 & 0 & 0 & 0 & 1,8 & $>0,2$ \\
\hline Tebal Kumulatif Pada Sisi Kanan (m) & 13,8 & 13,8 & 13,8 & 13,8 & 13,8 & 15,6 & $>15,8$ \\
\hline rentang qc $\left(\mathrm{kg} / \mathrm{cm}^{\wedge}{ }^{2}\right)$ & $20-40$ & $16-20$ & $20-32$ & $14-18$ & $6-12$ & $40-80$ & $>160$ \\
\hline$\gamma$ sat $\left(\mathrm{kN} / \mathrm{m}^{\wedge} 3\right)$ & 18 & 17 & 17 & 16 & 15 & 20 & 22 \\
\hline runsat $\left(\mathrm{kN} / \mathrm{m}^{\wedge} 3\right)$ & 15 & 15 & 15 & 15 & 14 & 16 & 16 \\
\hline c $(\mathrm{kN} / \mathrm{m} 2)$ & 21 & 19 & 20 & 13 & 5 & - & - \\
\hline$\Phi\left(^{0}\right)$ & 25 & 23 & 28 & 16 & 14 & 35 & 45 \\
\hline $\mathrm{E}(\mathrm{kN} / \mathrm{m} 2)$ & 13000 & 15000 & 17000 & 25000 & 5500 & 25000 & 50000 \\
\hline $\mathrm{v}^{\prime}$ & 0,36 & 0,36 & 0,36 & 0,38 & 0,4 & 0,3 & 0,2 \\
\hline Cc & 0,184285 & 0,202941 & 0,18793103 & 0,21071 & 0,475 & - & - \\
\hline Cc & 0,084285 & 0,102941 & 0,08793103 & 0,11071 & 0,375 & - & - \\
\hline Cs & 0,008428 & 0,010294 & 0,00879310 & 0,01107 & 0,0375 & - & - \\
\hline $\mathrm{e} 0$ & 0,506084 & 0,540631 & 0,51283524 & 0,55502645 & 1,04444444 & - & - \\
\hline Kx, Ky (m/day) & 0,000008 & 0,000008 & 0,00000864 & 0,00000864 & 0,00000864 & 7,128 & 7,1280 \\
\hline $\mathrm{Ck}$ & 0,253042 & 0,270315 & 0,25641762 & 0,27751322 & 0,52222222 & - & - \\
\hline
\end{tabular}


Tabel 4. Parameter Tanah Cell 2 Bagian 1

\begin{tabular}{|c|c|c|c|c|c|}
\hline Daerah & & & Cell 2 & & \\
\hline Nomor Lapisan & 1 & 2 & 3 & 4 & 5 \\
\hline Jenis Tanah & $\begin{array}{c}\text { Organic Clays } \\
\text { And Mixed Soils }\end{array}$ & $\begin{array}{l}\text { Organic Clays } \\
\text { And Mixed Soils }\end{array}$ & Stiff Clay & Stiff Clay & Stiff Clay \\
\hline Tipe & Undrained & Undrained & Undrained & Undrained & Undrained \\
\hline Tebal Lapisan Pada Sisi Kiri (m) & 2,4 & 0 & 4 & 2,8 & 3,8 \\
\hline Tebal Kumulatif Pada Sisi Kiri (m) & 2,4 & 2,4 & 6,4 & 9,2 & 13 \\
\hline Tebal Lapisan Pada Sisi Tengah (m) & 2,2 & 1,8 & 4,2 & 0,6 & 0 \\
\hline Tebal Kumulatif Pada Sisi Tengah (m) & 2,2 & 4 & 8,2 & 8,8 & 8,8 \\
\hline Tebal Lapisan Pada Sisi Kanan (m) & 2,2 & 1,8 & 2 & 3 & 0 \\
\hline Tebal Kumulatif Pada Sisi Kanan (m) & 2,2 & 4 & 6 & 9 & 9 \\
\hline rentang qc $\left(\mathrm{kg} / \mathrm{cm}^{\wedge} 2\right)$ & $4-8$ & $6-11$ & $11-17$ & $17-22$ & $10-17$ \\
\hline$\gamma$ sat $\left(\mathrm{kN} / \mathrm{m}^{\wedge} 3\right)$ & 14 & 15 & 16 & 17 & 16 \\
\hline runsat $\left(\mathrm{kN} / \mathrm{m}^{\wedge} 3\right)$ & 13 & 14 & 15 & 15 & 15 \\
\hline c $(\mathrm{kN} / \mathrm{m} 2)$ & 4 & 5 & 10 & 15 & 13 \\
\hline$\Phi\left({ }^{\circ}\right)$ & 11 & 14 & 16 & 18 & 16 \\
\hline$\Psi\left(^{0}\right)$ & - & - & - & - & - \\
\hline $\mathrm{E}(\mathrm{kN} / \mathrm{m} 2)$ & 5000 & 6000 & 10000 & 13000 & 10000 \\
\hline $\mathrm{v}^{\prime}$ & 0,4 & 0,38 & 0,38 & 0,36 & 0,38 \\
\hline Cc & 0,6500 & 0,3118 & 0,1607 & 0,2618 & 0,1607 \\
\hline Cs & 0,0650 & 0,0312 & 0,0161 & 0,0262 & 0,0161 \\
\hline $\mathrm{e} 0$ & 1,5537 & 0,9273 & 0,6476 & 0,8347 & 0,6476 \\
\hline Kx, Ky (m/day) & 0,0000086 & 0,0000086 & 0,0000086 & 0,0000086 & 0,0000086 \\
\hline $\mathrm{Ck}$ & 0,7769 & 0,4637 & 0,3238 & 0,4174 & 0,3238 \\
\hline
\end{tabular}

Tabel 5. Parameter Tanah Cell 2 Bagian 2

\begin{tabular}{|c|c|c|c|c|}
\hline \multirow{2}{*}{$\frac{\text { Daerah }}{\text { Nomor Lapisan }}$} & \multicolumn{4}{|c|}{ Cell 2} \\
\hline & 6 & 7 & 8 & 9 \\
\hline Jenis Tanah & $\begin{array}{l}\text { Organic Clays } \\
\text { And Mixed Soils }\end{array}$ & $\begin{array}{c}\text { Sandy And Silty } \\
\text { Clays }\end{array}$ & Sand & Sand \\
\hline Tipe & Undrained & Undrained & Undrained & Undrained \\
\hline Tebal Lapisan Pada Sisi Kiri (m) & 0 & 1 & 1,8 & 0,6 \\
\hline Tebal Kumulatif Pada Sisi Kiri (m) & 13 & 14 & 15,8 & 16,4 \\
\hline Tebal Lapisan Pada Sisi Tengah (m) & 3,2 & 0,2 & 1,8 & 0,4 \\
\hline Tebal Kumulatif Pada Sisi Tengah (m) & 12 & 12,2 & 14 & 14,4 \\
\hline Tebal Lapisan Pada Sisi Kanan (m) & 3,4 & 0,4 & 1,2 & 0,4 \\
\hline Tebal Kumulatif Pada Sisi Kanan (m) & 12,4 & 12,8 & 14 & 14,4 \\
\hline rentang qc $\left(\mathrm{kg} / \mathrm{cm}^{\wedge} 2\right)$ & $9-14$ & $20-40$ & $80-160$ & $>160$ \\
\hline$\gamma$ sat $\left(\mathrm{kN} / \mathrm{m}^{\wedge} 3\right)$ & 15 & 18 & 21 & 22 \\
\hline runsat $\left(\mathrm{kN} / \mathrm{m}^{\wedge} 3\right)$ & 14 & 15 & 16 & 16 \\
\hline c $(\mathrm{kN} / \mathrm{m} 2)$ & 7 & 21 & - & - \\
\hline$\Phi\left({ }^{0}\right)$ & 15 & 25 & 40 & 45 \\
\hline$\Psi\left({ }^{0}\right)$ & - & - & - & - \\
\hline $\mathrm{E}(\mathrm{kN} / \mathrm{m} 2)$ & 7000 & 13000 & 35000 & 50000 \\
\hline $\mathrm{v}^{\prime}$ & 0,38 & 0,36 & 0,25 & 0,2 \\
\hline Cc & 0,2438 & 0,1843 & - & - \\
\hline Cc & 0,1938 & 0,1343 & - & - \\
\hline Cs & 0,0194 & 0,0134 & - & - \\
\hline $\mathrm{e} 0$ & 0,7088 & 0,5987 & - & - \\
\hline Kx, Ky (m/day) & 0,0000086 & 0,0000864 & 7,1280000 & 7,1280000 \\
\hline $\mathrm{Ck}$ & 0,3544 & 0,2993 & - & - \\
\hline
\end{tabular}


Tabel 6. Parameter Tanah Cell 3 Bagian 1

\begin{tabular}{|c|c|c|c|c|c|}
\hline Daerah & & & Cell 3 & & \\
\hline Nomor Lapisan & 1 & 2 & 3 & 4 & 5 \\
\hline Jenis Tanah & $\begin{array}{l}\text { Organic Clays } \\
\text { And Mixed } \\
\text { Soils }\end{array}$ & $\begin{array}{l}\text { Organic Clays } \\
\text { And Mixed } \\
\text { Soils }\end{array}$ & $\begin{array}{l}\text { Organic Clays } \\
\text { And Mixed } \\
\text { Soils }\end{array}$ & $\begin{array}{l}\text { Organic Clays } \\
\text { And Mixed } \\
\text { Soils }\end{array}$ & $\begin{array}{c}\text { Organic Clays } \\
\text { And Mixed } \\
\text { Soils }\end{array}$ \\
\hline Tipe & Undrained & Undrained & Undrained & Undrained & Undrained \\
\hline Tebal Lapisan Pada Sisi Kiri (m) & 2 & 3,2 & 2,4 & 1,8 & 1,8 \\
\hline Tebal Kumulatif Pada Sisi Kiri (m) & 2 & 5,2 & 7,6 & 9,4 & 11,2 \\
\hline Tebal Lapisan Pada Sisi Tengah (m) & 1,6 & 0 & 5,6 & 0,6 & 0 \\
\hline Tebal Kumulatif Pada Sisi Tengah (m) & 1,6 & 1,6 & 7,2 & 7,8 & 7,8 \\
\hline Tebal Lapisan Pada Sisi Kanan (m) & 3 & 4,8 & 1,4 & 1,6 & 0 \\
\hline Tebal Kumulatif Pada Sisi Kanan (m) & 3 & 7,8 & 9,2 & 10,8 & 10,8 \\
\hline rentang qc $\left(\mathrm{kg} / \mathrm{cm}^{\wedge} 2\right)$ & $0-4$ & $5-8$ & $8-12$ & $3-8$ & $10-17$ \\
\hline$\gamma$ sat $\left(\mathrm{kN} / \mathrm{m}^{\wedge} 3\right)$ & 14 & 14 & 15 & 14 & 16 \\
\hline runsat $\left(\mathrm{kN} / \mathrm{m}^{\wedge} 3\right)$ & 13 & 13 & 14 & 13 & 14 \\
\hline c $(\mathrm{kN} / \mathrm{m} 2)$ & 2 & 4 & 5 & 4 & 13 \\
\hline$\Phi\left({ }^{0}\right)$ & 10 & 13 & 14 & 13 & 16 \\
\hline $\mathrm{E}(\mathrm{kN} / \mathrm{m} 2)$ & 4500 & 5000 & 5500 & 5000 & 10000 \\
\hline$v^{\prime}$ & 0,4 & 0,4 & 0,38 & 0,4 & 0,38 \\
\hline $\mathrm{Cc}$ & 0,7200 & 0,4500 & 0,3118 & 0,5000 & 0,1607 \\
\hline Cs & 0,0720 & 0,0450 & 0,0312 & 0,0500 & 0,0161 \\
\hline e0 & 1,6833 & 1,1833 & 0,9273 & 1,2759 & 0,6476 \\
\hline Kx, Ky (m/day) & 0,0000086 & 0,0000086 & 0,0000086 & 0,0000086 & 0,0000086 \\
\hline $\mathrm{Ck}$ & 0,8417 & 0,5917 & 0,4637 & 0,6380 & 0,3238 \\
\hline
\end{tabular}

Tabel 7. Parameter Tanah Cell 3 Bagian 2

\begin{tabular}{|c|c|c|c|c|c|c|}
\hline \multirow{2}{*}{$\begin{array}{c}\text { Daerah } \\
\text { Nomor Lapisan }\end{array}$} & \multicolumn{6}{|c|}{ Cell 3} \\
\hline & 6 & 7 & 8 & 9 & 10 & 11 \\
\hline Jenis Tanah & $\begin{array}{c}\text { Organic } \\
\text { Clays And } \\
\text { Mixed Soils }\end{array}$ & Stiff Clay & $\begin{array}{l}\text { Clayey Sands } \\
\text { And Silt }\end{array}$ & Sand & Sand & Sand \\
\hline Tipe & Undrained & Undrained & Undrained & Drained & Drained & Drained \\
\hline Tebal Lapisan Pada Sisi Kiri (m) & 1,2 & 0 & 0 & 1,4 & 0 & 0,2 \\
\hline Tebal Kumulatif Pada Sisi Kiri (m) & 12,4 & 12,4 & 12,4 & 13,8 & 13,8 & 14 \\
\hline Tebal Lapisan Pada Sisi Tengah (m) & 1 & 2 & 0,8 & 1,2 & 0,2 & 0,2 \\
\hline Tebal Kumulatif Pada Sisi Tengah (m) & 8,8 & 10,8 & 11,6 & 12,8 & 13 & 13,2 \\
\hline Tebal Lapisan Pada Sisi Kanan (m) & 0,6 & 0 & 0,4 & 1 & 0 & 0,4 \\
\hline Tebal Kumulatif Pada Sisi Kanan (m) & 11,4 & 11,4 & 11,8 & 12,8 & 12,8 & 13,2 \\
\hline rentang qc $\left(\mathrm{kg} / \mathrm{cm}^{\wedge} 2\right)$ & $20-30$ & $14-20$ & $24-34$ & $40-80$ & $80-160$ & $>160$ \\
\hline$\gamma$ sat $\left(\mathrm{kN} / \mathrm{m}^{\wedge} 3\right)$ & 17 & 15 & 18 & 20 & 21 & 22 \\
\hline runsat $\left(\mathrm{kN} / \mathrm{m}^{\wedge} 3\right)$ & 14 & 14 & 15 & 16 & 16 & 16 \\
\hline c $(\mathrm{kN} / \mathrm{m} 2)$ & 18 & 10 & 20 & - & - & - \\
\hline$\Phi\left({ }^{0}\right)$ & 25 & 16 & 28 & 35 & 40 & 45 \\
\hline $\mathrm{E}(\mathrm{kN} / \mathrm{m} 2)$ & 15000 & 7000 & 16000 & 25000 & 35000 & 50000 \\
\hline $\mathrm{v}^{\prime}$ & 0,36 & 0,38 & 0,36 & 0,3 & 0,25 & 0,2 \\
\hline Cc & 0,1879 & 0,2065 & 0,1879 & - & - & - \\
\hline $\mathrm{Cc}$ & 0,1379 & 0,1565 & 0,1379 & - & - & \\
\hline Cs & 0,0138 & 0,0156 & 0,0138 & - & - & - \\
\hline $\mathrm{e} 0$ & 0,6054 & 0,6397 & 0,6054 & - & - & - \\
\hline Kx, Ky (m/day) & 0,0000086 & 0,0000086 & 0,0000086 & 7,1280000 & 7,1280000 & 7,1280000 \\
\hline $\mathrm{Ck}$ & 0,3027 & 0,3199 & 0,3027 & - & - & - \\
\hline
\end{tabular}


Tabel 8. Parameter Tanah Cell 4 Bagian 1

\begin{tabular}{|c|c|c|c|c|c|}
\hline Daerah & & & Cell 4 & & \\
\hline Nomor Lapisan & 1 & 2 & 3 & 4 & 5 \\
\hline Jenis Tanah & $\begin{array}{l}\text { Organic Clays } \\
\text { And Mixed } \\
\text { Soils }\end{array}$ & Medium Clay & $\begin{array}{l}\text { Organic Clays } \\
\text { And Mixed } \\
\text { Soils }\end{array}$ & $\begin{array}{l}\text { Organic Clays } \\
\text { And Mixed } \\
\text { Soils }\end{array}$ & $\begin{array}{c}\text { Organic Clays } \\
\text { And Mixed } \\
\text { Soils }\end{array}$ \\
\hline Tipe & Undrained & Undrained & Undrained & Undrained & Undrained \\
\hline Tebal Lapisan Pada Sisi Kiri (m) & 3 & 3,6 & 1,6 & 0,6 & 0 \\
\hline Tebal Kumulatif Pada Sisi Kiri (m) & 3 & 6,6 & 8,2 & 8,8 & 8,8 \\
\hline Tebal Lapisan Pada Sisi Tengah (m) & 7,2 & 2,8 & 0,4 & 0 & 0,6 \\
\hline Tebal Kumulatif Pada Sisi Tengah (m) & 7,2 & 10 & 10,4 & 10,4 & 11 \\
\hline Tebal Lapisan Pada Sisi Kanan (m) & 1,4 & 1,6 & 0 & 0 & 3,4 \\
\hline Tebal Kumulatif Pada Sisi Kanan (m) & 1,4 & 3 & 3 & 3 & 6,4 \\
\hline rentang qc $\left(\mathrm{kg} / \mathrm{cm}^{\wedge} \wedge 2\right)$ & $0-4$ & $4-9$ & $2-7$ & $8-10$ & $10-16$ \\
\hline$\gamma$ sat $\left(\mathrm{kN} / \mathrm{m}^{\wedge} 3\right)$ & 14 & 14 & 14 & 15 & 15 \\
\hline zunsat $\left(\mathrm{kN} / \mathrm{m}^{\wedge} 3\right)$ & 13 & 13 & 13 & 14 & 14 \\
\hline c $(\mathrm{kN} / \mathrm{m} 2)$ & 2 & 4 & 3 & 5 & 10 \\
\hline$\Phi\left(^{0}\right)$ & 10 & 13 & 12 & 14 & 16 \\
\hline $\mathrm{E}(\mathrm{kN} / \mathrm{m} 2)$ & 4500 & 5000 & 4750 & 6000 & 6500 \\
\hline $\mathrm{v}^{\prime}$ & 0,4 & 0,4 & 0,4 & 0,38 & 0,38 \\
\hline Cc & 0,5200 & 0,3500 & 0,4500 & 0,3118 & 0,2227 \\
\hline Cc & 0,7200 & 0,5500 & 0,6000 & 0,3118 & 0,1727 \\
\hline Cs & 0,0720 & 0,0550 & 0,0600 & 0,0312 & 0,0173 \\
\hline $\mathrm{e} 0$ & 1,6833 & 1,3685 & 1,4611 & 0,9273 & 0,6699 \\
\hline Kx, Ky (m/day) & 0,0000086 & 0,0000086 & 0,0000086 & 0,0000086 & 0,0000086 \\
\hline $\mathrm{Ck}$ & 0,8417 & 0,6843 & 0,7306 & 0,4637 & 0,3349 \\
\hline
\end{tabular}

Tabel 9. Parameter Tanah Cell 4 Bagian 2

\begin{tabular}{|c|c|c|c|c|c|c|}
\hline \multirow{2}{*}{$\begin{array}{c}\text { Daerah } \\
\text { Nomor Lapisan }\end{array}$} & \multicolumn{6}{|c|}{ Cell 4} \\
\hline & 6 & 7 & 8 & 9 & 10 & 11 \\
\hline Jenis Tanah & Stiff Clay & $\begin{array}{c}\text { Organic } \\
\text { Clays And } \\
\text { Mixed Soils }\end{array}$ & $\begin{array}{c}\text { Clayey Sands } \\
\text { And Silt }\end{array}$ & Sand & Sand & Sand \\
\hline Tipe & Undrained & Undrained & Undrained & Drained & Drained & Drained \\
\hline Tebal Lapisan Pada Sisi Kiri (m) & 0,4 & 0,8 & 1,2 & 0,2 & 0,6 & 0,6 \\
\hline Tebal Kumulatif Pada Sisi Kiri (m) & 9,2 & 10 & 11,2 & 11,4 & 12 & 12,6 \\
\hline Tebal Lapisan Pada Sisi Tengah (m) & 0 & 0 & 0 & 0,6 & 0 & 0,2 \\
\hline Tebal Kumulatif Pada Sisi Tengah (m) & 11 & 11 & 11 & 11,6 & 11,6 & 11,8 \\
\hline Tebal Lapisan Pada Sisi Kanan (m) & 2 & 6,2 & 0 & 0 & 0,6 & 0,2 \\
\hline Tebal Kumulatif Pada Sisi Kanan (m) & 8,4 & 14,6 & 14,6 & 14,6 & 15,2 & 15,4 \\
\hline rentang qc $(\mathrm{kg} / \mathrm{cm} \wedge 2)$ & $16-22$ & $4-10$ & $12-20$ & $50-90$ & $120-160$ & $>160$ \\
\hline$\gamma$ sat $\left(\mathrm{kN} / \mathrm{m}^{\wedge} 3\right)$ & 17 & 13 & 16 & 20 & 21 & 22 \\
\hline runsat $\left(\mathrm{kN} / \mathrm{m}^{\wedge} 3\right)$ & 15 & 14 & 15 & 16 & 16 & 16 \\
\hline c $(\mathrm{kN} / \mathrm{m} 2)$ & 15 & 5 & 12 & - & - & - \\
\hline$\Phi\left({ }^{0}\right)$ & 18 & 14 & 17 & 35 & 40 & 45 \\
\hline $\mathrm{E}(\mathrm{kN} / \mathrm{m} 2)$ & 10000 & 5500 & 8000 & 26000 & 35000 & 50000 \\
\hline$v^{\prime}$ & 0,36 & 0,38 & 0,36 & 0,3 & 0,25 & 0,2 \\
\hline Cc & 0,2000 & 0,3500 & 0,2107 & - & - & - \\
\hline Cc & 0,1500 & 0,3000 & 0,1607 & - & - & - \\
\hline Cs & 0,0150 & 0,0300 & 0,0161 & - & - & - \\
\hline $\mathrm{e} 0$ & 0,6278 & 0,9056 & 0,6476 & - & - & - \\
\hline Kx, Ky (m/day) & 0,0000086 & 0,0000086 & 0,0000086 & 7,1280000 & 7,1280000 & 7,1280000 \\
\hline $\mathrm{Ck}$ & 0,3139 & 0,4528 & 0,3238 & - & - & - \\
\hline
\end{tabular}




\section{Hasil analisis program elemen hingga}

Setelah semua tahapan pemodelan selesai di analsis, maka hasil penurunan dan pergerakan lateral dapat dilakukan verifikasi hasil terhadap parameter yang digunakan. Digunakan hasil penurunan dan pergerakan lateral pada tanggal 14 Oktober (hari ke 260 sesuai data lapangan). Digunakan analisis dengan material soft soil model.

Berdasarkan perbandingan analisis program elemen hingga, kurva perbandingan pergerakan lateral pada cell 1 dan cell 2 terlihat mirip. Namun perbandingan kurva pergerakan lateral pada cell 3 dan cell 4 berbeda.

Berdasarkan hasil analisis pada cell 1, pergerakan lateral telah menunjukan nilai yang cukup sesuai dengan hasil monitoring. Hasil analisis dapat di lihat pada gambar 7 dan gambar 8.

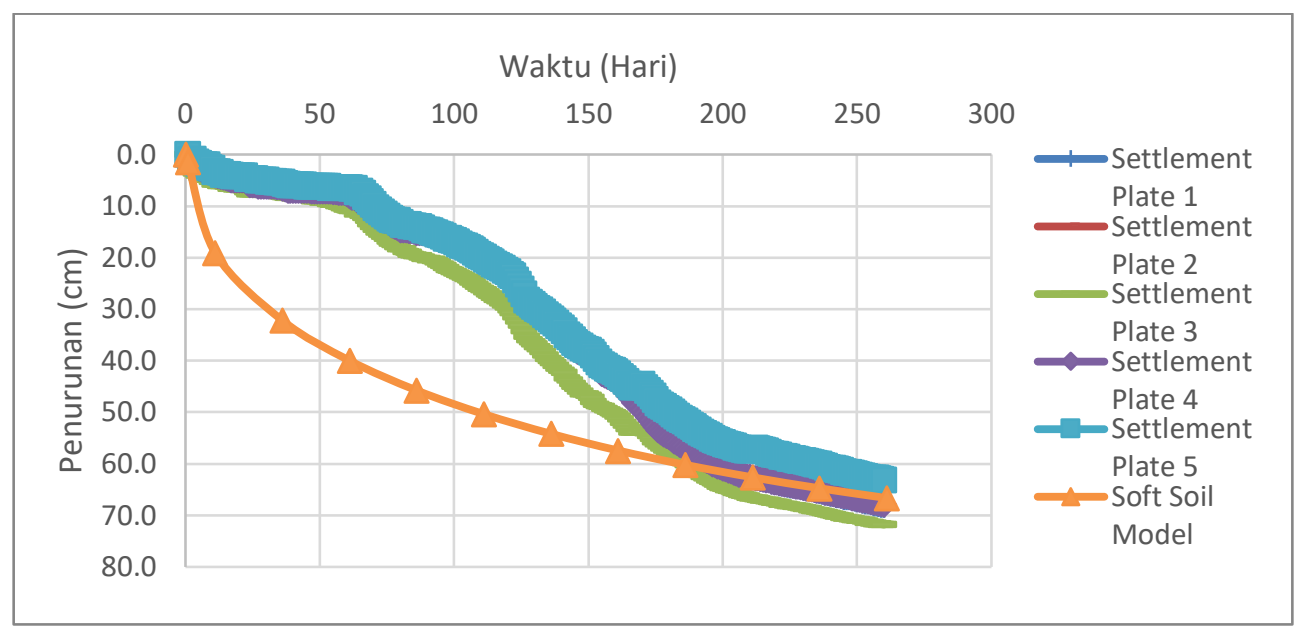

Gambar 7. Kurva perbandingan penurunan terhadap waktu pada cell 1

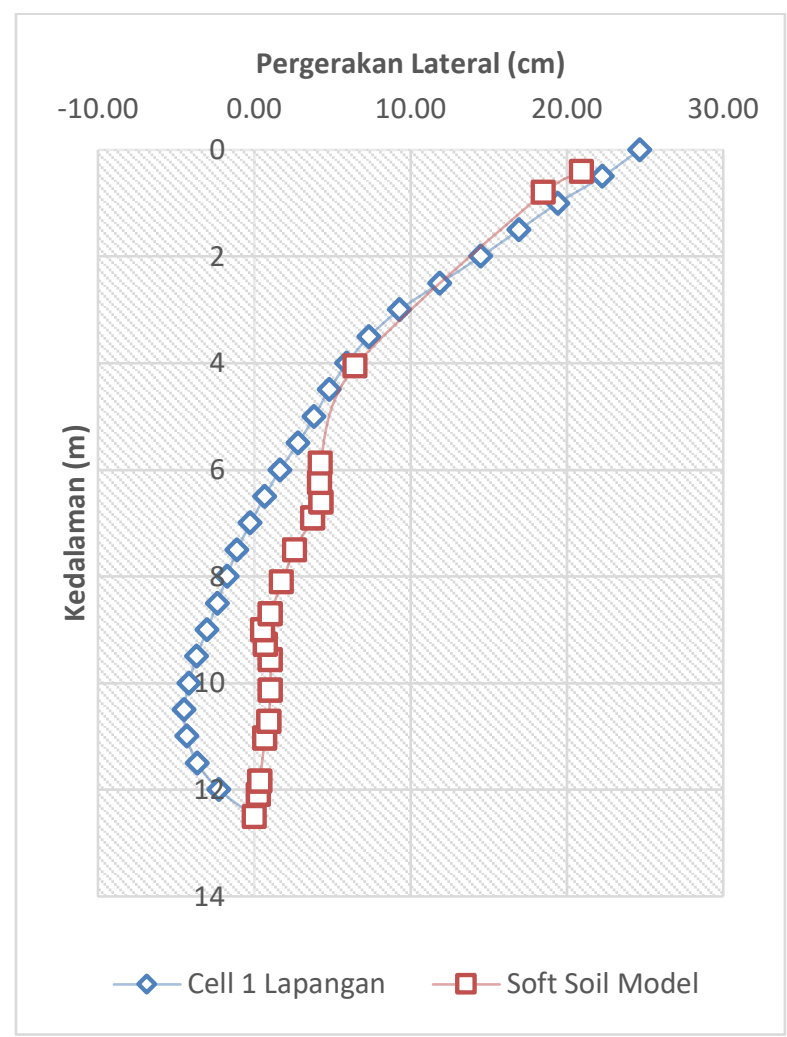


Gambar 8. Grafik perbandingan pergerakan lateral inklinometer dan hasil analisis cell 1

Berdasarkan hasil analisis pada cell 2, pergerakan lateral telah menunjukan nilai yang cukup sesuai dengan hasil monitoring. Hasil analisis dapat di lihat pada gambar 9 dan gambar 10.

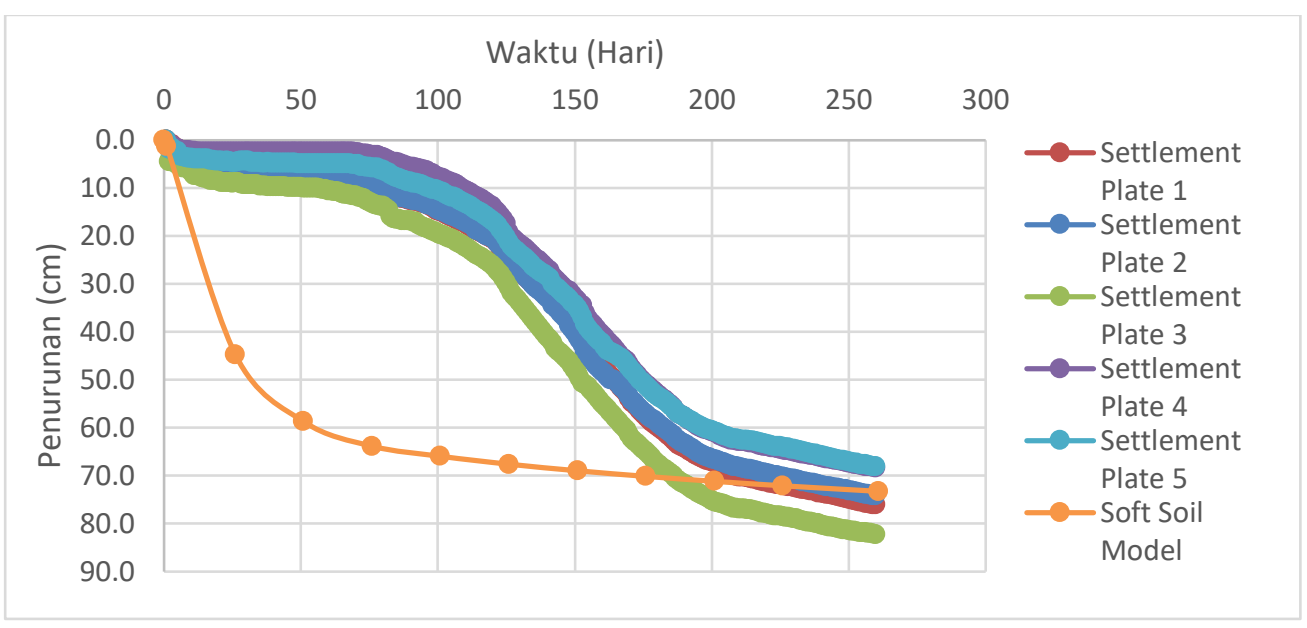

Gambar 9. Kurva perbandingan penurunan terhadap waktu pada cell 2

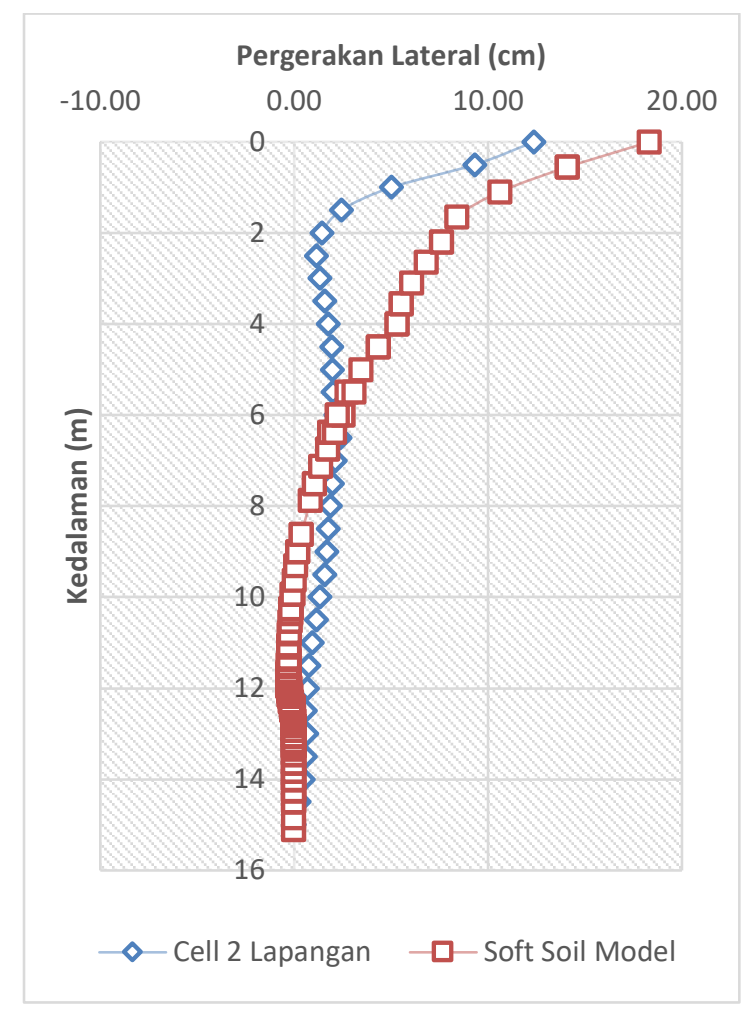

Gambar 10. Grafik perbandingan pergerakan lateral inklinometer dan hasil analisis cell 2

Berdasarkan hasil analisis pada cell 3, pergerakan lateral telah menunjukan nilai tidak sesuai dengan hasil monitoring. Hasil analisis dapat di lihat pada gambar 11 dan gambar 12 


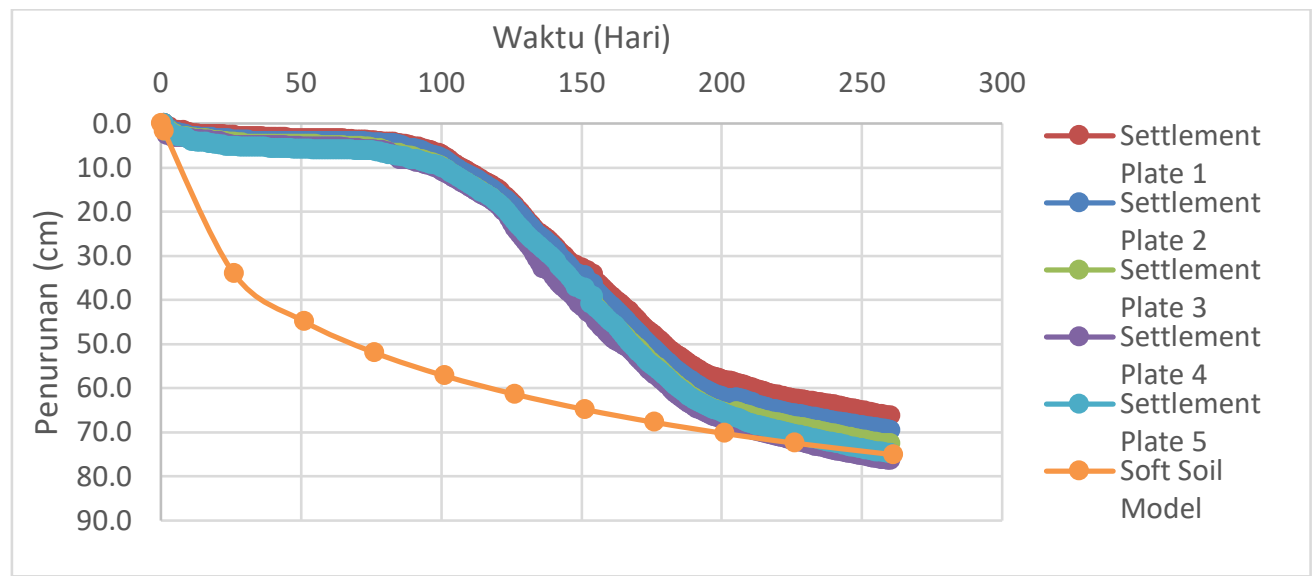

Gambar 11. Kurva perbandingan penurunan terhadap waktu pada cell 3

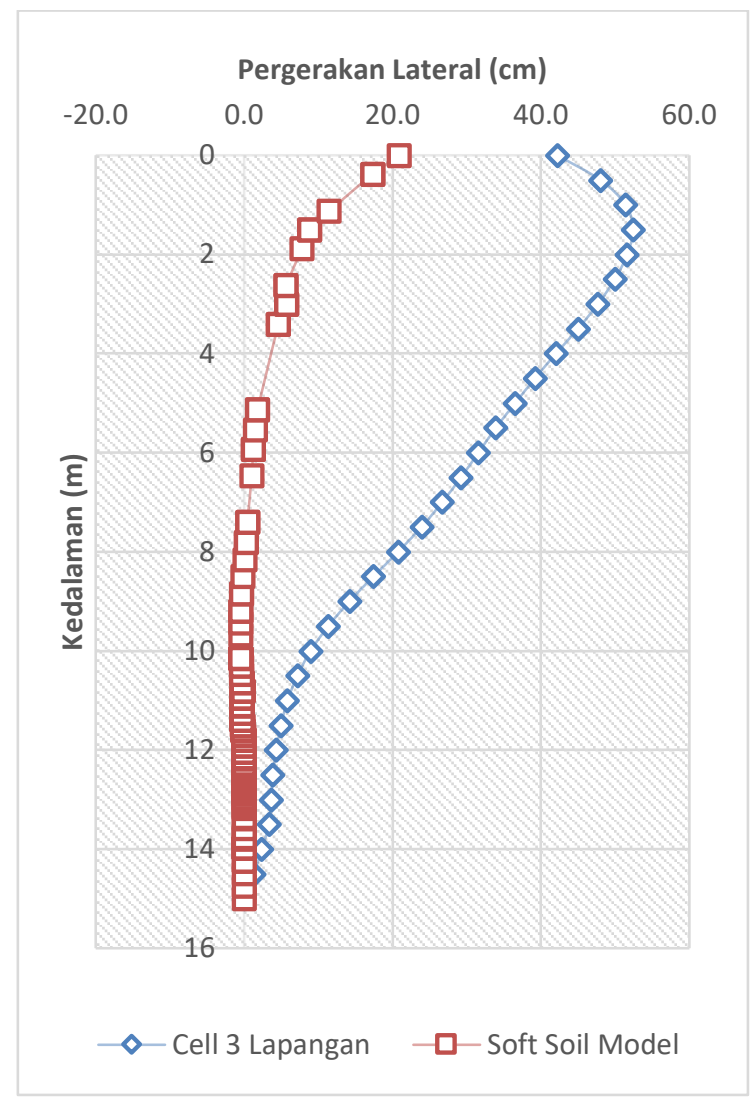

Gambar 12. Grafik perbandingan pergerakan lateral inklinometer dan hasil analisis cell 3

Berdasarkan hasil analisis pada cell 4, pergerakan lateral telah menunjukan nilai tidak sesuai dengan hasil monitoring. Hasil analisis dapat di lihat pada gambar 13 dan 14. 


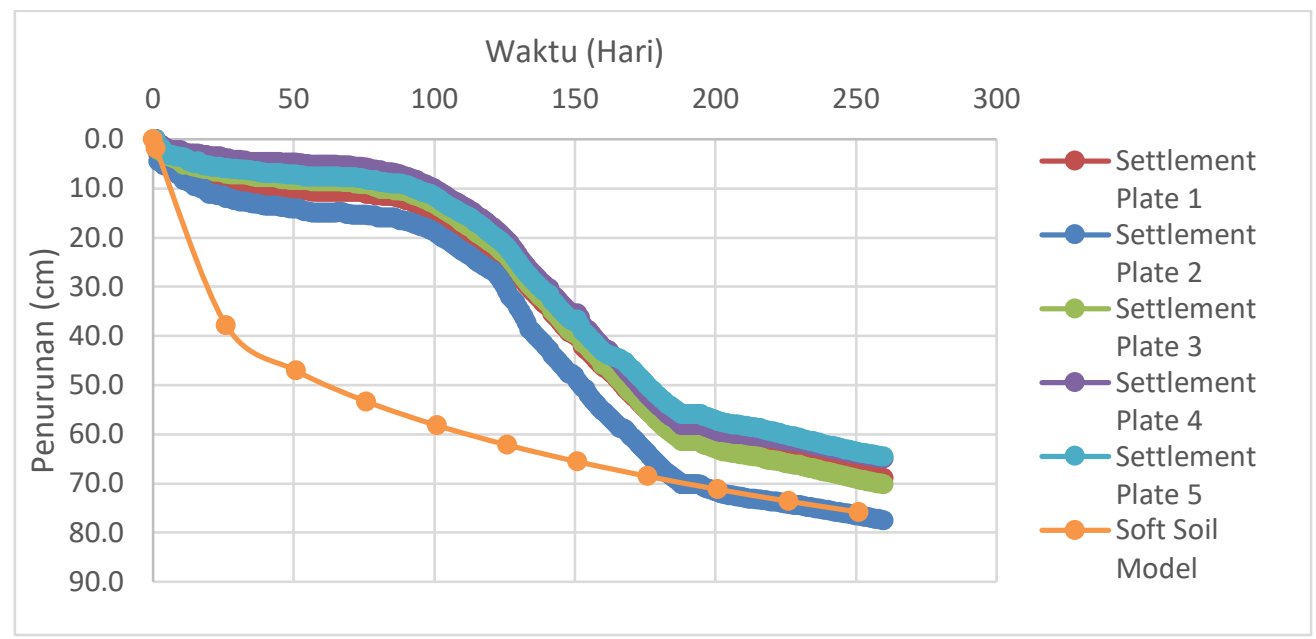

Gambar 13. Kurva perbandingan penurunan terhadap waktu pada cell 4

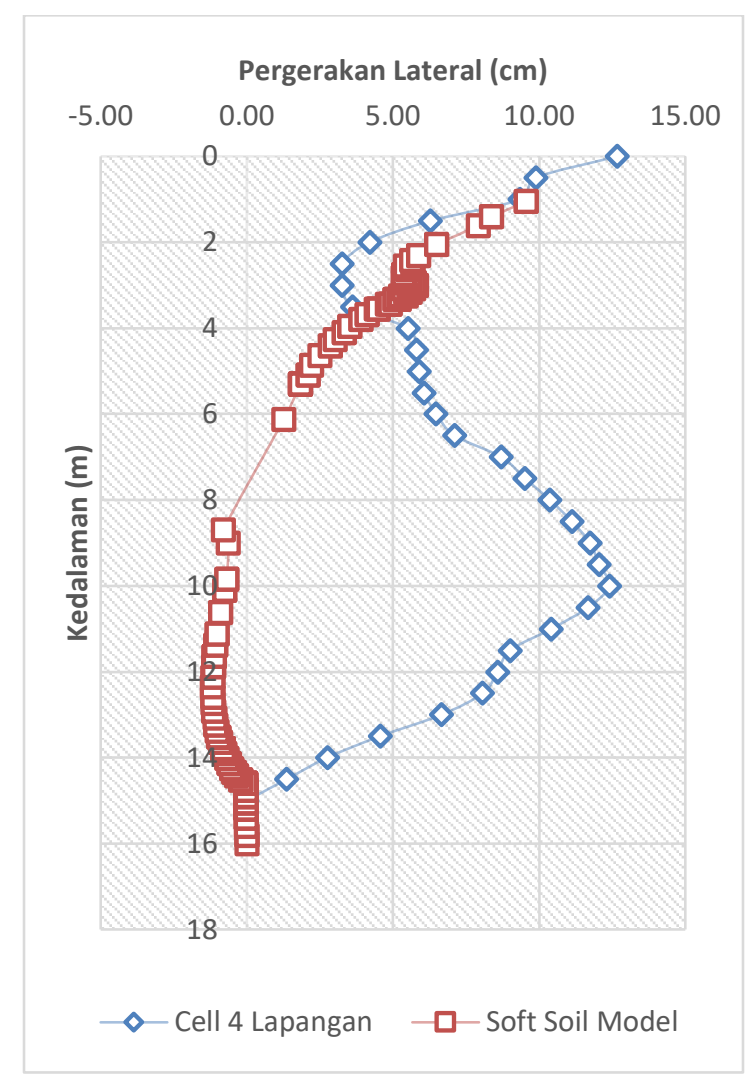

Gambar 14. Grafik perbandingan pergerakan lateral inklinometer dan hasil analisis cell 4

Dilihat dari analisis untuk hasil pergerakan lateral, sistem vacuum menarik tanah kedalam daerah perbaikan, sehingga pola grafik nya akan cekung ke kanan. Namun data lapangan cell 3 dan 4 menunjukan grafik yang anomali. Hal ini bisa terjadi karena adanya kemungkinan keruntuhan pada lubang inklinometer, ataupun kesalahan pembacaan pada inklinometer.

Berdasarkan hasil analisis program elemen hingga, didapatkan hasil jarak pengaruh pergerakan lateral di luar batas perbaikan. Hasil analisis dan pemodelan dapat dilihat pada gambar 15 hingga gambar 18. 


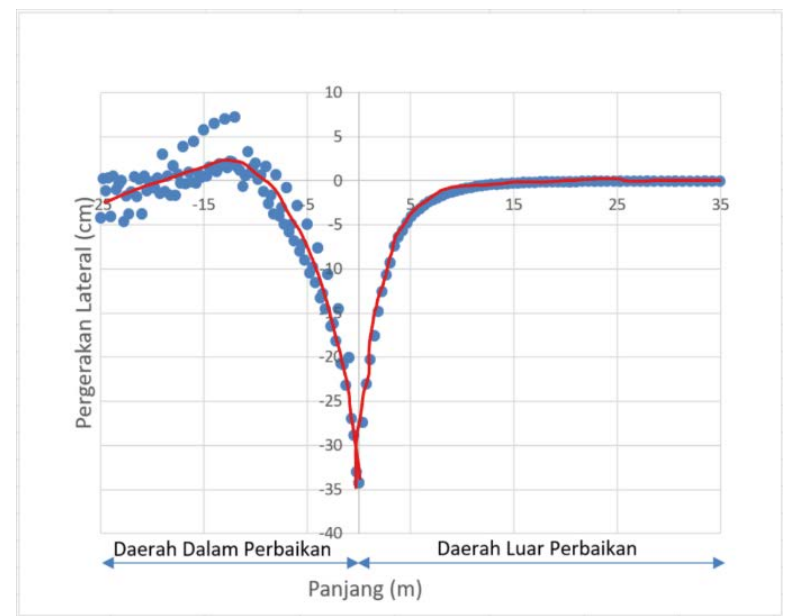

Gambar 15. Grafik jarak pengaruh pergerakan lateral cell 1

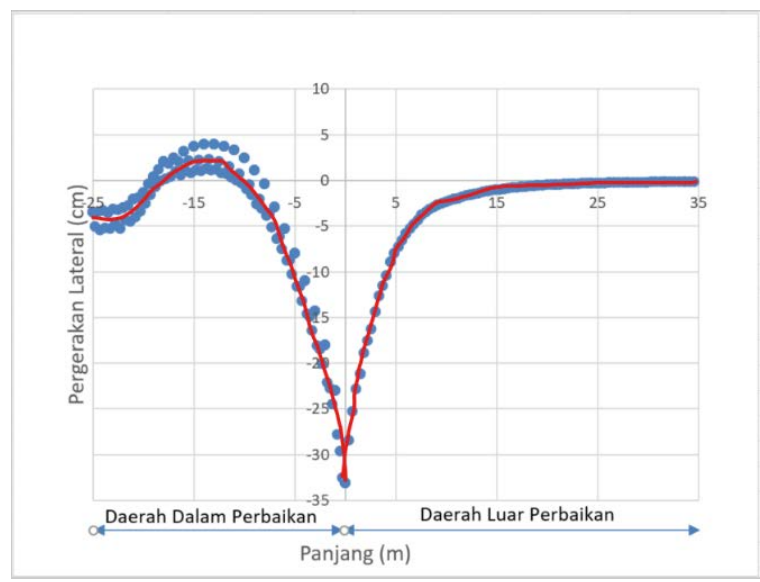

Gambar 16. Grafik jarak pengaruh pergerakan lateral cell 2

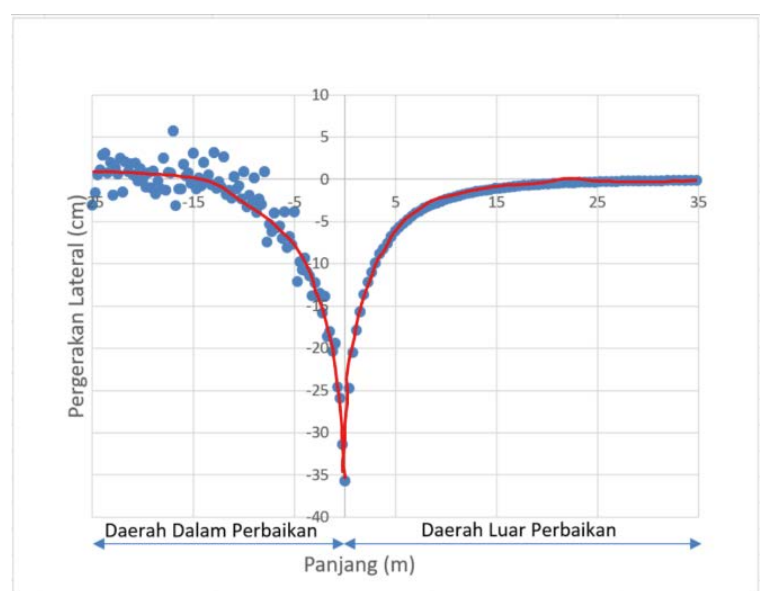

Gambar 17. Grafik jarak pengaruh pergerakan lateral cell 3 


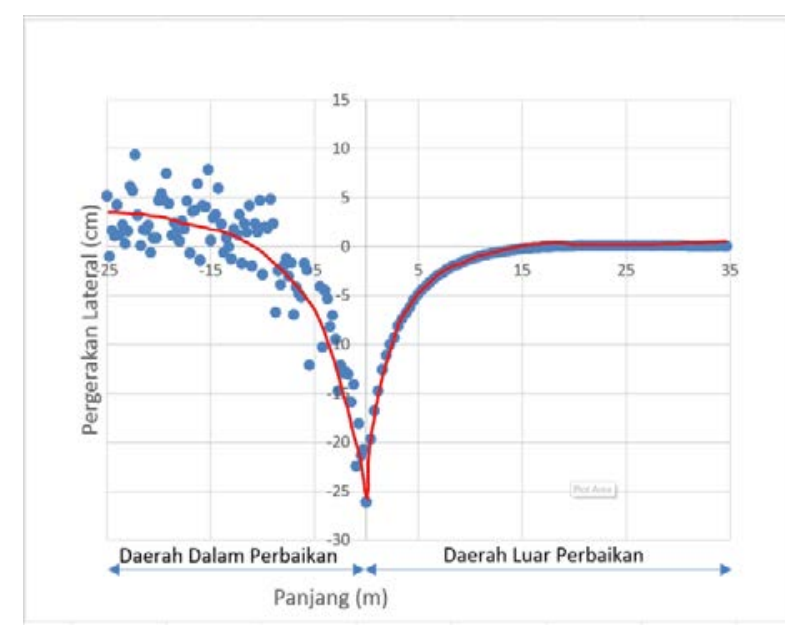

Gambar 18. Grafik jarak pengaruh pergerakan lateral cell 4

Berikut tabel hasil penurunan di lapangan dan program pada tabel 10 serta jarak pengaruh akibat pergerakan lateral setiap cell pada tabel 11 .

Tabel 10. Penurunan pada setiap cell

\begin{tabular}{cccccc}
\hline Penurunan $(\mathrm{cm})$ & Hari & cell 1 & cell 2 & cell 3 & cell 4 \\
\hline \multirow{4}{*}{ Program } & 51 & 32,16 & 58,71 & 44,85 & 47,11 \\
& 101 & 50,35 & 65,94 & 57,17 & 58,21 \\
& 176 & 60,19 & 70,13 & 67,74 & 68,56 \\
& 260 & 66,64 & 73,25 & 75,05 & 75,81 \\
& 51 & 7,60 & 5,70 & 3,40 & 10,30 \\
Lapangan & 101 & 17,40 & 17,60 & 17,60 & 17,40 \\
& 176 & 53,10 & 56,84 & 53,82 & 55,28 \\
& 260 & 67,98 & 73,76 & 71,90 & 69,24 \\
\hline
\end{tabular}

Tabel 11. Jarak pengaruh setiap cell

\begin{tabular}{ccc}
\hline Daerah & $\begin{array}{c}\text { Kedalaman } \\
\text { PVD }(\mathrm{m})\end{array}$ & $\begin{array}{c}\text { Jarak Pengaruh Akibat } \\
\text { Pergerakan Lateral* }(\mathrm{m})\end{array}$ \\
\hline cell 1 & 12,5 & 10,79 \\
cell 2 & 15 & 11,23 \\
cell 3 & 15 & 8,06 \\
cell 4 & 15 & 8,87 \\
*akibat pergerakan lateral yang lebih dari $2 \mathrm{~cm}$
\end{tabular}

Berdasarkan tabel hasil pergerakan lateral pada keempat cell, cell 2 mempunyai jarak pengaruh terbesar, yaitu 11,23m. Sementara jarak abutment ke daerah perbaikan 15m. Maka menurut pemodelan di program, pergerkan lateral pada proyek perbaikan tanah vacuum preloading tidak mempengaruhi abutment di sekitarnya.

\section{KESIMPULAN DAN SARAN}

\section{Kesimpulan}

Dari hasil penulisan ini didapatkan beberapa kesimpulan yaitu:

1. Berdasarkan analisis dari program elemen hingga, jarak pengaruh akibat pergerakan lateral yang lebih dari $2 \mathrm{~cm}$ pada keempat cell adalah:

\begin{tabular}{ccc}
\hline Daerah & $\begin{array}{c}\text { Kedalaman } \\
\text { PVD }(\mathrm{m})\end{array}$ & $\begin{array}{c}\text { Jarak Pengaruh Akibat } \\
\text { Pergerakan Lateral* (m) }\end{array}$ \\
\hline cell 1 & 12,5 & 10,79 \\
cell 2 & 15 & 11,23 \\
cell 3 & 15 & 8,06 \\
cell 4 & 15 & 8,87 \\
\hline
\end{tabular}


2. Jarak pengaruh akibat pergerakan lateral akibat metode perbaikan tanah vacuum preloading dikombinasikan dengan PVD di jalan tol Bekasi, dimana pergerakan lateral yang yang dihitung adalah lebih dari 2cm pada daerah adalah 11,23m. Oleh karena itu, pergerakan lateral tersebut tidak terpengaruh oleh abutment dimana jaraknya $15 \mathrm{~m}$ dari luar batas perbaikan.

3. Berdasarkan perbandingan analisis program elemen hingga, kurva perbandingan penurunan tidak sesuai dengan hasil dengan lapangan. Hal ini bisa terjadi karena pola pembebanan yang di analisis tidak sama dengan yang terjadi di lapangan.

4. Berdasarkan perbandingan analisis program elemen hingga, kurva perbandingan pergerakan lateral pada cell 1 dan cell 2 terlihat mirip. Namun perbandingan kurva pergerakan lateral pada cell 3 dan cell 4 berbeda. Hal ini bisa terjadi karena adanya kemungkinan keruntuhan pada lubang inklinometer, ataupun kesalahan pembacaan pada inklinometer.

\section{Saran}

Berdasarkan hasil analisis yang dilakukan, adapun beberapa saran yang meliputi:

1. Menggunakan data-data selain data boring dan sondir, yaitu data hasil uji laboratorium sehingga analisis parameter tanah dapat lebih tepat dibandingkan dengan hasil korelasi.

2. Penelitian dapat dikembangkan untuk mendapatkan metode pengendalian sehingga dapat mengurangi atau menghilangkan pengaruh deformasi lateral yang disebabkan oleh vacuum preloading.

3. Menggunakan pemodelan pada program yang lebih bervariatif, seperti pemodelan hardening soil ataupun mohr-coulomb.

\section{DAFTAR PUSTAKA}

Andryan Suhendra, M. I. (2011). Studi Aplikasi Vacuum Preloading sbagai Metode Alternatif Percepatan Proses Konsolidasi pada Tanah Lempung Lunak Jenuh Air: Trial GVS pada Perumahan Pantai Indah Kapuk, Jakarta. ComTech Vol.2.

Badan Standarisasi Nasional. (2017). SNI 8460:2017 Persyaratan Perencanaan Geoteknik. Jakarta.

Chu, J. Y. (2008). Vacuum Preloading Techniques - Recent Developments and Applications. In Proceedings of ASCE GeoConggress: Geosustainability and Geohazard Mitigations, New Orleans, ASCE, Reston, VA.

Das, B. M. (1985). Mekanika Tanah (Prinsip-Prinsip Rekayasa Geoteknik) Jilid I. Jakarta: Erlangga.

Das, B. M. (1994). Mekanika Tanah II (Prinsip-prinsip Rekayasa Geoteknis) Jilid 1 dan 2. Jakarta: Erlangga.

Indraratna, B. R. (2005). Prediction and Observations of Soft Clay Fondations Stabilized with Geosynthetic drain Vacuum Surcharge. Ground Improvement - Case Histories Book, Edited by Indraratna, B. And Chu, J. Elsevier. London.

Lay, M. O., Sumarli, I., \& Iskandar, A. (2020). Studi Parametrik Jarak Pengaruh Penurunan dan Pergerakan Lateral Akibat Vacuum Pre-Loading Pada Damage Area Sekitar. Jurnal Mitra Teknik Sipil, Vol.3, No. 4, 10911104.

Mochtar, I. B. (2000). Teknologi Perbaikan Tanah dan Alternatif Perencanaan pada Tanah Bermasalah. Surabaya: Jurusan Teknik Sipil FTSP-ITS.

Sanglerat. (1972). The Penetrometer and Soil Exploration. 
Analisis Metode Perbaikan Tanah Vacuum Preloading terhadap Struktur Abutment di Sekitarnya

Steven Djunawan, et al. 